\title{
DVASINIS ASISTAVIMAS KAIP INTEGRALI DVASINĖS PAGALBOS DALIS
}

\author{
Vaineta Juškienè, Jolita Navickienè \\ Klaipèdos universitetas
}

\begin{abstract}
Anotacija
Dvasinis aspektas yra vienas esminių žmogiškosios egzistencijos sandu, tad tampa integralia holistinès pagalbos žmogui dalimi. Krikščioniškoji dvasinè pagalba ịvairiomis formomis pamažu įsitvirtina mūsu šalyje ir bandoma apibrèžti tiek juridiniu, tiek teologiniu ar psichologiniu aspektais, tad būtinas atidesnis žvilgsnis ir detalesnè analize. Atsižvelgiant i šia problematika straipsnyje analizuojami krikščioniškojo dvasinio asistavimo bruožai dvasingumo sampratos kontekste, jo santykis su psichologine pagalba. Aptariamos aktualios dvasingumo traktuotès, dvasinio ir psichologinio konsultavimo bruožai, dvasinio asistavimo kristocentriškumo svarba.

PAGRINDINIAI ŽODŽIAI: dvasingumas, dvasinis asistavimas, dvasinis konsultavimas.
\end{abstract}

\begin{abstract}
The spiritual aspect is one of essential components of human existence; therefore, it becomes an integral part of holistic support to a human being. Christian spiritual assistance in its various forms is becoming gradually established in our country, and there are attempts to define it in both juridical and theological or psychological aspects. Therefore, it requires a deeper glance and a more detailed analysis. In relation to this problem, the article deals with features of Christian spiritual assistance in the context of perception of spirituality and its relation to psychological support. Relevant approaches to spirituality, features of spiritual and psychological counselling as well as importance of Christ-centred spiritual assistance are discussed. KEY WORDS: spirituality, spiritual assistance, spiritual counseling.
\end{abstract}

DOI: http://dx.doi.org/10.15181/mtd.v0i7.2310

\section{Ivadas}

Spartūs įvairiapusiai pokyčiai dabarties pasaulyje vis labiau išryškina tvarumo ir trapumo dialektiką, kuri iškelia egzistencines žmogaus problemas bei giluminius klausimus. Pandeminio laikotarpio realybe dar labiau išryškino problematikas, kurioms spręsti žmogus neretai pasitelkia ne tik asmeninę, bet ir įvairių sričių specialistų pagalbą. Siekiant išlaikyti asmenybės darną ir 
dvasinę sveikatą svarbu integraliai žvelgti ị psichologinę ir religinę šių problemų ịveikos dimensijas. Tokia perspektyva skatina gręžtis ị krikščioniškają pagalbą, kurios aktualizavimas gali reikšmingai prisidèti padedant išlaikyti dvasinę pusiausvyrą, savivertę, prasmę ir orumą - esminius žmogaus, kaip dvasingo asmens, bruožus. Dvasinis konsultavimas ir asistavimas yra viena iš minètos pagalbos formų, šiandien jau pradèta pripažinti Lietuvos Respublikos įstatymuose (Lietuvos Respublikos sveikatos apsaugos ministro įsakymas „Dèl sielovados patarnavimų teikimo sveikatos priežiūros įstaigose“, 2009; Lietuvos Respublikos Vyriausybės nutarimas „Dèl bazinio paslaugų šeimai paketo patvirtinimo“, 2019) ir pamažu ịsitvirtinanti kaip pagalbos praktika ịvairiose gyvenimo realybėse. Vis dèlto neretai dar kyla diskusijų dèl koncepcinių šio pobūdžio pagalbos aspektų, terminologijos ar apibrèžtumo. Atsižvelgiant ị tai ir keliamas šio straipsnio tikslas - atskleisti krikščioniškojo dvasinio asistavimo bruožus dvasingumo sampratos kontekste, jo santyki su psichologine pagalba. Tikslo siekiama taikant tyrimo metodus: literatūros analizès, sisteminimo, interpretacijos.

Tiriamasis žvilgsnis paremtas humanistine nuostata, pabrėžiančia dvasini asmens pradą, kaip esmini igimtą žmogaus bruožą. Remiantis šiuo požiūriu, žmogus yra nuolatinio dvasinio tapsmo procese. Krikščioniškas dvasinis asistavimas tampa integralia minèto tapsmo dalimi.

\section{Dvasingumo sampratos daugiaaspektiškumas}

Dvasingumo sąvoka dẻl savo daugiaaspektiškumo ir dèl to, kad nèra empirinio tyrimo objektas, vis dar sunkiai apibrèžiama, kelia nemažai diskusijų ir nesutarimų. Dvasingumo negalima išmatuoti kiekybine skaičių kalba, nustatyti griežtas teorinio, loginio matavimo ribas. Žvelgiant filosofiškai, jis reiškiasi asmens gebejjimu suvokti būties prasmę, pilnatvę, tad tampa kertiniu brandžios asmenybės bruožu. Plačiausia prasme dvasingumas siejasi su religinėmis ir moralinėmis vertybėmis, kurios konkrečiai reiškiasi kaip gyvenimo nuostata arba yra tam tikras nusistatymas, duodantis pagrindą veiksmams. Šiuo požiūriu dvasingumas kuria nors viena religija neapribojamas. Jis taikomas kiekvienam žmogui, kuris tiki Dievu ar transcendencija ir gyve- 
nimą formuoja pagal savo religinius ịsitikinimus. Galima sakyti, kad dvasingumas yra ypatinga gyvybiška vertybių sintezè, formuojama pagal skirtingus požiūrio ar išryškinimo taškus. Dvasingumo pagrindas - universali vertybinè orientacija ir tvirta moralinè nuostata. Dvasingumas - proto ir jausmų harmonija (Šiaudvytytė, 2005). Remiantis Helen'a Lavretsky (2010) tyrimų apibendrinimais, dvasingumas gali būti suprantamas kaip šventumo arba savojo Aš paieškos, siekiant šventumo.

Dvasingumo apibrèžimai laikui bėgant keitèsi, o pastaraisiais dešimtmečiais dvasingumas vis dažniau laikomas psichinès ir fizinès sveikatos konstravimo pagrindu. 1971 m. Jungtinèse Amerikos Valstijose ịkurta Nacionalinè tarpreliginè senejjimo koalicija (angl. The National Interfaith Coalition on Aging), dvasinę gerovę apibrěžusi kaip gyvenimo priemima per santykị su Dievu, savimi, bendruomene ir aplinka, nes visa tai puoselejja bei skelbia integralumą (Lavretsky, 2010).

Harriet'a Mowat, Maureen O’Neill (2013) ì dvasingumą siūlo žvelgti iš šių pozicijų:

- Dvasingumas, kaip religinio ịsitikinimo dalis: tai savita tikèjimo, dorybių, idealų ir principų sistema, formuojanti tam tikrą kelią Dievo, tad ir gyvenimo apskritai link (pvz., pranciškoniškasis, stačiatikių, monastinis, misijų dvasingumas).

- Dvasingumas, kaip pasaulietinè samprata: tai idejjos, praktikos, pasišventimai, kurie puoselëja, palaiko ir formuoja tiek individualų, tiek bendruomeninį žmogaus gyvenimą.

- Dvasingumas, kaip prasmés paieškos su Dievu ar be Jo: dvasingumas pripažįsta žmonių poreiki pasiekti galutinę gyvenimo prasmę, nesvarbu, tai įvyktų per santykị su Dievu ar kokiu kitu būdu. Žmogaus dvasingumas gali būti susijęs su kitais žmonèmis.

Ronald'as Rolheiser'is (2017) akcentuoja, kad dvasingumas yra gana naujas anglų kalbos žodis, bent jau ta reikšme, kuria ji vartojame šiandien. Jo teigimu, Vakarų pasaulyje, ypač sekuliariame, ši sąvoka dažnai vis dar neteisingai suprantama. Dažniausia manoma, kad dvasingumas yra kažkas egzotiško, ezoteriško, pakylèto virš kasdienybès ir rutinos. Daugeliui žmonių žodis 
dvasingumas asocijuojasi su tuo, kas neịprasta, mistiška, nepažintu Bažnyčios gyvenimu, šventumu, nuolankumu, kitoniškumu, su tuo, kas neva skirta tik išrinktiesiems. H. Lavretsky (2010) paantrino, kad tradiciškai dvasingumo terminas vartotas labai religingam asmeniui apibūdinti, bet šiandien jo vartosena gerokai išsiplète, įtraukdama tiek religijos, tiek gerovès bei laimès ieškotoją, tiek ir eilinị pasaulietį. Nors įsitikinimai ir nuomonès skirtingi, daugelis žmonių dvasingumą ir religiją aiškiai skiria. Tiesą sakant, dažnai religija yra tik vienas iš galimų dvasingumo kelių. „Nors dvasingumas yra dažnai tapatinamas su žmogaus religingumu, tačiau tai yra du skirtingi, nors komplementarūs, vienas kitą papildantys reiškiniai“ (Šeškevičius ir kt., 2011, p. 110).

\begin{tabular}{|c|c|}
\hline Dvasingumas & Religija \\
\hline Plati, subjektyvi, unifikuojanti sąvoka & Tiksliai apibrěžta ir struktūruota \\
\hline Neformalus ir nedominacinis & Formali ir denominacinė \\
\hline Ypač asmeninis ir nedogminis & $\begin{array}{c}\text { Sutelkta ties bendruomene, ritualais ir } \\
\text { tam tikromis doktrinomis }\end{array}$ \\
\hline I jausmus orientuotas & I elgesị orientuota \\
\hline I vidų nukreipta patirtis & Išorinė patirtis, turint vidinės naudos \\
\hline
\end{tabular}

1 pav. Dvasingumo ir religijos skirtumai

Šaltinis: remiantis Redd, 2017

Daug rečiau dvasingumas mūsų gyvenime suprantamas kaip nediskutuotinas esminès svarbos dalykas. Jis nesietinas su paribiais - saujele išrinktųjų. Kiekvienas esame vienaip ar kitaip dvasingas - mūsų dvasingumas gali teikti gyvybę arba ją naikinti. Dvasingumas neturi nieko bendra su natūraliai kylančiu ar sąmoningu apsisprendimu imtis kokios nors dvasinès veiklos: eiti ị bažnyčią, melstis ar medituoti, skaityti dvasinę literatūrą ar imtis dvasinių pratybų. Tai daug gilesnis dalykas. Taigi, anot R. Rolheiser'io, nepaisant mūsų noro ar religingumo, kiekvienas esame dvasingas. Mūsų dvasingumas lemia mūsų veiksmus. O tai, kas lemia mūsų veiksmus, iš esmès lemia ir troš- 
kimus. Troškimas skatina veikti, veikdami pasiekiame didesnị asmenybės, proto ir kūno integralumą - sustipriname arba sumenkiname savo santykị su Dievu, žmonėmis ir pasauliu. Tai leidžia mums teigti, kad dvasingumą apibrèžia mūsų elgesys su savo siela. R. Rolheiser'is prieina prie išvados, kad sveika siela teikia mums energijos. Dvasingo žmogaus priešingybẻ - būtybè, kuriai trūksta gyvenimo jègos. Kita svarbi sielos užduotis - padèti mums išlikti vientisiems, integraliems, kad savęs neiššvaistytume. Tuo požiūriu dvasingojo priešingybe - žmogus, praradęs savo tapatybę, nebežinantis, kas jis toks yra. Turime žinoti, kas esame, kur einame ir kokia viso to prasmè. Sveika siela padeda mums išlikti gyvybingiems ir integraliems. Sielą R. Rolheiser'is (2017) apibrèžè kaip ne tai, ką turime, labiau - kas esame. Tai gyvybès pulsavimas, dẻl ko esame gyvi. Siela tarsi „suklijuoja“ mūsų širdị ir protą. Mumyse gyvena siela, o mūsų dvasingumas yra tai, kaip su ja elgiamès.

Krikščioniškoji antropologija (cit. remiantis Skinkaitis, 2016, p. 79-84) kūną ir sielą traktuoja kaip nedalomą vienį, juos sieja dvasia: žmogus yra ir kūnas, ir siela. Jų atskirumas yra tik santykinis ir galimas tik metafiziniame plane. Tai dviejų pradų nedalomos vienybès personalizmo samprata, kurią ypač išplètojo šv. Tomas Akvinietis. Jis pateikè du šios sampratos aspektus: 1) kūnas yra sielos forma, o siela sudvasina kūną; 2) žmogaus esmè - kūnas ir siela - pradeda egzistuoti vienu aktu ir vienu metu. Dvasinis žmogaus pradas ateina tiesiogiai iš Dievo ir susijungia su kūnu žmogaus prokreacinio pradejjimo metu. Taigi krikščioniškasis tikejjimas moko, kad žmogus yra vientisas asmuo. Siela save išreiškia pasirodydama kūne. Pati būdama forma, o ne žmogaus dalis, ji leidžia atsirasti žmogui ir daro jị tuo, kas jis yra. Dvasiné žmogaus tikrovè reiškiasi per kūną. Dvasios veikiamas žmogus tobulèja, vystosi ir bręsta.

R. Rolheiser'is (2017), kalbėdamas apie dvasingumą, skiria krikščioniškaji dvasinguma, kuris yra dvasinis kiekvieno žmogaus, norinčio tapti Kristaus mokiniu, iššūkis. Šis dvasingumas remiasi keturiais svarbiais ramsčiais, kuriais pagrịstas Kristaus mokymas: individuali malda ir asmens dora; socialinis teisingumas; širdies ir dvasios linksmumas bei bendruomeniškumas, be kurio neįmanomas tikras Dievo garbinimas. Tai ne pasirinkimo dalykas, kuris galètų būti sudètinè mūsų dvasinio gyvenimo dalis. Šie kriterijai sudaro 
dvasinio gyvenimo esmę, kuri padeda išlaikyti vidinę pusiausvyrą. Krikščionybèje dvasingumas neatsiejamas nuo Jèzaus Kristaus asmens. Krikščioniškas dvasingumas apima tris pagrindinius dalykus: tikejjimo žinias, vertybių skalę ir gyvenimo būdą. Jis išgyvenamas kaip asmeninè patirtis socialinèje ir kultūrinèje erdvejje bei pasireiškia praktiniais žmogaus veiksmais (Karaliūtè, 2001). Plačiaja prasme krikščionybejje dvasingumas reiškia ,gyvenimą iš dvasios", kuris reiškia sąmoningą, subjektyvią laikyseną žmoguje esančios Šventosios Dvasios atžvilgiu ir tikejjimo praktiką. Dvasios akcentavimas nereiškia žmogiškujų jausmų ir pojūčių atsisakymo ar atsiribojimo nuo pasaulio (žr. Vorgrimler, 2003, p. 160). Peter'io Scazzero (2018) teigimu, šiuolaikinèje krikščionybejje trūksta emocinès brandos ir kontempliatyvaus dvasingumo (kalbejjimas Dievui; kalbejjimas su Dievu; Dievo klausymasis; buvimas su Dievu) derinio, kuris mumyse išlaisvintų Šventają Dvasią, per kurią galètume patirti autentiško gyvenimo Kristuje jègą:

- Išsilaisvinu nuo savojo netikrojo Aš sluoksnių, nusimetu juos, kad galètų pasirodyti mano tikrasis Aš Kristuje.

- Išsilaisvinu suvokdamas, kad viskas yra ne tai, kaip atrodo; mano gyvenimo stabai sudūžta atskleidus jų pažadų iliuziją; iš naujo pamatau savo gyvenimą Kristuje ir sèkmę suvokiu kitaip nei ją mato pasaulis.

- Išsilaisvinu nuo iliuzijos, kad gyvensiu amžinai; kontempliatyvusis dvasingumas kasdien man primena mano žemiškojo gyvenimo trapumą ir amžinybès realumą.

- Išsilaisvinu nuo savanaudiškų troškimų, nuolat mane tolinančių nuo Dievo, kad vykdyčiau savo, o ne jo valią (cit. remiantis Scazzero, 2018, p. 62).

Krikščioniškojo dvasingumo centras, objektas ir tikslas yra Dievas, kuris reiškiasi asmeniniame žmogaus gyvenime. Tad krikščioniškasis dvasingumas yra tarpasmeninis dvasingumas ir žmogaus gyvenimas su Dievu (Karaliūtè, 2001). Žmogus, sekantis Jèzaus mokymu, mokosi kontempliatyvaus transcendentinio santykio, kartu tampa atidesnis sau ir artimui. 


\section{Dvasinio asistavimo samprata, santykis su psichologiniu konsultavimu}

Asistavimas lotynų kalba (assisto) reiškia stovèti šalia; (lot.) assistere - dalyvauti, padèti; asistentas (lot. assistens) - padedantis (Tarptautinių žodžių žodynas, 1985). Dvasinio asistavimo sąvoka lietuvių mokslineje literatūroje vis dar iki galo aiškiai neapibrèžta, dažnai ji sinonimiškai vartojama kartu su dvasinio konsultavimo sąvoka. Nors dvasinis asistavimas ir dvasinis konsultavimas - glaudžiai susiję dalykai, nederètų jų tapatinti, žvelgti kaip į skirtingus procesus. Vienas iš kriterijų, kuriais būtų galima apibrèžti dvasinio asistavimo sąvoką, - remtis dvasinio asistento pareigybès aprašu, kuris pateiktas LR sveikatos apsaugos ministro įsakyme „Dèl sielovados patarnavimų teikimo sveikatos priežiūros įstaigose“ (2009 m. liepos 24 d. Isakymo Nr. V-639). Remiantis minètu aprašu, dvasinis asistavimas tai: 1) dvasinès pagalbos teikimas; 2) pagalba teikiant religinius patarnavimus pacientams, jų artimiesiems ir darbuotojams. Remiantis šiuo aprašu, dvasinio asistento pareigas apima katalikų tikèjimo mokymo ir moralès principų laikymasis, nors plačiaja prasme toks dvasinio asistavimo apibrěžimas gali būti taikomas bet kurios kitos religinès bendruomenès ar kitų religinių judèjimų atstovams. Ką reiškia teikti religinius patarnavimus - mažai diskusijų keliantis klausimas, nes tai susiję su aiškiai apibrěžiamais liturginiais veiksmais, kuriuos gali atlikti diakonas, vienuolis ar pasaulietis, turintis raštišką vyskupo siuntimą vykdyti ligonių sielovadą (lot. missio canonica): tai asmeninè ir bendra malda, užtariamoji malda bei budejimas, Šventojo Rašto ir kiti dvasiniai skaitymai, pagalba rengiant liturgiją, paruošimas sakramentams, malda ir patarnavimai mirties atveju arba gedint. Daugiau svarstymų, norint vienareikšmiškai apibrèžti dvasinio asistavimo sąvoką, sukelia kita dvasinio asistento funkcija - dvasinès pagalbos teikimas, kurios vykdymas minėtame įsakyme nusakytas kaip asmeniniai ir bendruomeniniai pokalbiai. Pokalbis gali būti kelių formų: žmogaus išklausymas, emocinis jo palaikymas ar tiesiog buvimas kartu tyloje (pasauliečiai savanoriai tai daro pasitelkdami telefonines emocinès paramos linijas: „Pagalbos moterims linija“, ,Jaunimo linija“, ,Sidabrinè linija"); tikslingas žmogaus problemų ir poreikių, sprendžiant dvasines, psichologines jo problemas, nustatymas (tam būtinas specialus pasirengimas ir tam tikros asmeninès savybès). Šiuo atveju dvasinio asistavimo supratimas persipina su dvasinio konsultavimo sąvoka ir sinergiškai įsilieja ị pastoracijos (sielovados) terminą, todèl čia atitinkamai būtų galima kalbèti apie sielovadini palydè128 
jimą. Kaip emocinès paramos linijose dirbantys savanoriai (jei tai ne specialistas konsultantas) teikia emocinę paramą, o ne psichologinę pagalbą, taip ir dvasinis asistentas nebūtinai bus ir dvasinis konsultantas, turbūt tokiu atveju tikslinga taip ir vadinti - dvasiniu asistentu. Taigi kalbėdami apie dvasinį konsultavimą galime sakyti, kad jis yra dvasinio asistavimo dalis, kitaip - asistavimas konsultuojant, tai psichologine ir dvasine parama sunkiais gyvenimo tarpsniais, siekiant padèti ịveikti dvasines krizes, egzistencinius asmeninius ir tarpasmeninius sunkumus, pažinti save ir atrasti dvasinę tikrovę (Lanauskienè, 2017).

Pagrindinis dvasinio ir psichologinio ar psichoterapinio konsultavimo skirtumas - psichologas, psichoterapeutas psichinès, psichologinès, dvasinès ar psichosomatinès ligos atveju remiasi medicinos ir psichiatrijos žiniomis bei gydymu, o dvasinis konsultantas natūralias gydymo priemones (medicina, psichiatrija) papildo antgamtiniais malonės šaltiniais (malda, sakramentai) ir siekia pavesti ligą Dievui (Redin, 2010; Jagelavičius, 2020; Bagdonè, 2020; Véželienè, 2018). Niujorko universiteto psichologijos profesorius Paul'as C. Vitz'as (cit. remiantis Véželiene, 2018, p. 38), savo veiklą grindžiantis krikščioniškaja pasaulěžiūra, sekuliariąją psichologiją ịvardija kaip narcisistinę, kuri turètų religijai grąžinti tai, kas priklauso sielogydai, o ne psichoterapijai, nes ignoruojant dvasinę žmogaus prigimties dali psichologiniai sunkumai tik apgydomi, bet ne išgydomi. „Žmogus kenčia ịvairiais būdais, kuriuos medicina, net pažangiausios jos specializacijos ne visada gali aprépti. (...) Čia kalbama apie dvasinio pobūdžio skausmą, ne tik apie moralinę ar kūno kančią lydinčio skausmo „psichinę“ dimensiją. Moralinė kančia, žinoma, tiek pat plati ir ivvairi kaip ir kūno kančia. Tačiau pirmosios kančios atveju tai ne taip aiškiai apibrěžiama ir ne taip lengvai pasiekiama terapijai“ (Jonas Paulius II, 1984). Krikščioniškoje sielogydoje įžvelgiamos trejopos psichikos ligu priežastys: organiškos, demoniškos ir dvasinès (Vèželienè, 2018). Bažnyčia ne tik nuolat ragina tikinčiuosius melsti savo ar savo artimujjų išgydymo, bet kreipia dèmesị ir ị Ligonių sakramento galią bei svarbą. Antrame paveiksle nurodytos keturios ligų rūšys ir penkios galimos jų priežastys, ištakos, nurodoma, koks natūralus gydymo būdas taikomas konkrečiai ligai ir koks galimas gydymo šaltinis yra susitikimas su Jėzumi per sakramentus bei sakramentalijas. 


\begin{tabular}{|c|c|c|c|c|}
\hline Liga & Priežastis & $\begin{array}{l}\text { Natūralus } \\
\text { gydymas }\end{array}$ & Malda & $\begin{array}{c}\text { Bažnyčios } \\
\text { pagalba }\end{array}$ \\
\hline Dvasinè & Nuodėmè & Nèra & $\begin{array}{c}\text { Prašant } \\
\text { atsivertimo }\end{array}$ & Išpažintis \\
\hline Psichinė & $\begin{array}{c}\text { Meilès stoka, } \\
\text { neprièmimas } \\
\text { ir t. t. }\end{array}$ & Psichiatrija & $\begin{array}{l}\text { Prisiminimų } \\
\text { išgydymo }\end{array}$ & $\begin{array}{c}\text { Eucharistija, } \\
\text { išpažintis }\end{array}$ \\
\hline Fizinè & $\begin{array}{c}\text { Infekcija, } \\
\text { nelaimingas } \\
\text { atsitikimas, kt. }\end{array}$ & Medicina & $\begin{array}{c}\text { Malda prašant } \\
\text { išgijimo }\end{array}$ & $\begin{array}{c}\text { Ligonio } \\
\text { patepimas, } \\
\text { Eucharistija }\end{array}$ \\
\hline $\begin{array}{c}\text { Psichosoma- } \\
\text { tinè }\end{array}$ & $\begin{array}{l}\text { Emociniai } \\
\text { konfliktai }\end{array}$ & $\begin{array}{c}\text { Psichiatrija, } \\
\text { medicina }\end{array}$ & $\begin{array}{l}\text { Prisiminimų } \\
\text { išgydymo }\end{array}$ & $\begin{array}{c}\text { Eucharistija, } \\
\text { išpažintis }\end{array}$ \\
\hline $\begin{array}{l}\text { Bet kuri iš } \\
\text { ankstesnių }\end{array}$ & $\begin{array}{l}\text { Piktosios } \\
\text { dvasios } \\
\text { puolimas }\end{array}$ & Nèra & $\begin{array}{c}\text { Prašant } \\
\text { išlaisvinimo }\end{array}$ & Egzorcizmas \\
\hline
\end{tabular}

2 pav. Liga, jos priežastys ir gydymas (remiantis Redin, 2010, p. 26)

Žmogaus kūnas visiškai priklausomas nuo jo dvasinès būsenos, emocijų: „Liga nèra tik kažkoks išorinis žmogų veikiantis veiksnys, ji paveikia pačius giliausius jo būties klodus. (...) Dažniausiai fizinị skausmą ar kančią lydi dvasinès ir sielos kančios, todèl žmogaus reakcijos ị kančią yra ne tik fiziologinès, bet ir neurologinès, elgesio tipo (bihevioristinès), psichinès“ (Ramonas, 2006, p. 155). Gydant vien tik kūną, žmogus nepasveiks. Nustatyta, kad asmenys, užsiimantys religine ir dvasine praktika, dažnai geriau susidoroja psichologiškai ir yra geresnès fizinès sveikatos, nei tie, kurie šiomis praktikomis neužsiima. Be to, nustatyta, kad dvasingumas palengvina fizinį, psichinị ar priklausomybès sutrikimą, pagerina gyvenimo kokybę, išlikimo situaciją (Šeškevičius ir kt., 2011; Pranckevičienė ir kt., 2012; Butėnaitė, 2019). Dvasinis asistavimas konsultuojant šioje perspektyvoje matomas kaip žmogaus lydẻjimas išbandymų akivaizdoje, siekis patenkinti individualius dvasinius poreikius. Tyrimai atskleidè (Advilonienè ir kt., 2018), kad Lietuvoje integralaus požiūrio ir praktikos derinant sielovadinị palydèjimą su medicininiu gydymu nèra, nors tiek medicinos, tiek sakramentų ir maldos taikymas sergančiam žmogui neprieštarauja vienas kitam, greičiau vienas kitą papildo. Medicina fiksuoja staigius 
nepaaiškinamus išgijimus po to, kai malda ir sakramentai panaikina kliūtis, kurios trukdè ligoniui pasveikti, pvz.: negalëjimas atleisti, kaltès jausmas, nusiminimas, baimè ir pan. (Redin, 2010). Atkreiptinas dėmesys, kad Kataliku Bažnyčia kviečia Ligonių patepimą priimti ne tik ligonius ar prieš sunkią operaciją, bet ir pagyvenusius asmenis, kai dèl amžiaus ima silpti jègos (Kataliku Bažnyčios Katekizmas, 2015, Nr. 1515). Krikščionybeje asmens sąvoka visada pirmesnè už apibūdinimą sergantis ar ligonis.

Abi - dvasinio asistavimo konsultuojant ir psichologinio konsultavimo sritys yra labai artimos, turi daug panašumo, nes žmogus yra kūnas, siela ir dvasia: jei gyvenimiška situacija susijusi su žmogaus psichika, tai ir su dvasiniu gyvenimu. Kita vertus, jos turi ir esminių skirtumų (Gubi, 2011). Psichologija yra mokslas apie žmogaus elgesį, jis domisi jausmais, taip pat ir religiniais išgyvenimais, bet nekelia Dievo egzistavimo klausimo (Pranckevičienė ir kt., 2012). Psichologas, psichoterapeutas atlieka žmogaus atspindžio vaidmenį, žmogaus gerovę sieja su aktyviomis psichologinėmis jo paties pastangomis sau padèti, viltis deda ị žmogaus savęs pažinimo ir ịvairių funkcionavimo ypatumų ịsisąmoninimo svarbą (Milašiūnas, 2017), tuo tarpu dvasinis asistentas konsultuodamas tik psichologine veikla neapsiriboja, jis remiasi Dievu, kaip sajungininku (Calame, 2020). Rèmimasis vien psichologine terapija dažnai atveria tuštumą, kurios kassavaitiniai susitikimai su psichoterapeutu neužpildo, nes dvasinis darbas, vykstantis su žmogaus siela, yra nenutrūkstamas procesas (Ramonas ir kt., 2013). Vykdant psichologinị konsultavimą laikomasi nuostatos, kad klientui patarimai dažniausia neduodami, tuo tarpu dvasinis asistentas-konsultantas gali naudotis Šventosios Dvasios patarimo dovana. Patarimo dovana padrąsina ieškoti išeičių, nes savo paieškose nesame vieni: Šventoji Dvasia suteikia reikalingų instrumentų - viltị ir aiškumą (Grun, 2014). Skirtingai nuo psichologo, psichoterapeuto, dvasinis asistentas stiprybės ieško dvasinejje tikrovejje. Kad žmogus pasveiktų, gali neužtekti vien tik išsiaiškinti jo somatines ir psichines bèdas.

Šioje mąstymo perspektyvoje reikia paminèti logoterapiją, „kur susiliečia medicina ir filosofija, o sielogyda balansuoja tarp medicinos ir religijos“ (Dulskis, 2008). Ši sistema, sukurta austrų neorologo ir psichiatro Viktor'o Emil'io Frankl'io, padeda žmogui ieškoti gyvenimo prasmès ir ją atrasti. Pasak Romu- 
aldo Dulskio (2008), logoterapija peržengia ribą, ties kuria sustoja daugelis psichoterapijos metodų. Gydymas gali būti neveiksmingas, neužčiuopus prasmès problematikos. V. Frankl'is yra pasakęs, kad logoterapija nėra psichoterapijos pakaitalas, ji tik padeda „sužmoginti“" psichoterapiją. Žinojimas, kad gyvenimas yra prasmingas, leidžia pakelti visus išgyvenimus. Gyvenimo prasmę galima surasti trimis būdais (cit. remiantis Perminas ir kt., 2004, p. 122):

1. Kažką duoti gyvenimui kuriant ar dirbant. Prasmingas ne pats darbas, o tai, ką unikalaus ir asmeniško žmogus jam suteikia.

2. Kažką imti iš gyvenimo ji patiriant. Pvz., gerumą, tiesą, grožį, gamtą, kultūrą. Galima patirti kito žmogaus unikalumą ji mylint. Meilè yra vienintelis būdas suprasti slapčiausią kito žmogaus esmę. Mylintis žmogus gali pamatyti esminius mylimo žmogaus bruožus ir padèti atsiskleisti jo galimybėms.

3. Paklusus likimui, kurio neịmanoma pakeisti, kartais kančia atsitraukia tą akimirką, kai atrandama jos prasmė, pvz., pasiaukojimas.

Trečiame paveiksle apibendrintai pateikti dvasinio asistavimo konsultuojant ir psichologinio konsultavimo skirtumai, laikantis nuostatos, kad dvasinis asistavimas konsultuojant paremtas kristocentriškumo (kristocentrizmas - krikščionių teologijos ir religingumo forma, kai Jėzus Kristus laikomas centriniu išganymo istorijoje bei krikščioniškame skelbime [Vorgrimler, 2003]), o psichologinis konsultavimas - psichologinių problemų sprendimo metodo principais.

Lietuvoje neatlikta tyrimų, kur būtų aptartos psichologų religinès nuostatos. Mokslinèje literatūroje nurodomos bendros psichologiją ir religini tikejjimą skiriančios priežastys: 1) sudètinga studijuoti dvasingumą kaip subjektyvų ir neapibrèžtą reiškinį; 2) psichologai nepakankamai vertina dvasingumo poveikị dèl jų mažesnio religingumo nei pati visuomené; 3) vyrauja psichologinių ir religinių bendruomenių tarpusavio konkurencija - vertybių, pasaulèžiūros ir išteklių požiūriais (cit. remiantis Butėnaite, 2019, p. 13). 


\begin{tabular}{|c|c|}
\hline Dvasinis asistavimas konsultuojant & Psichologinis konsultavimas \\
\hline $\begin{array}{l}\text { Santykis: Dievo vaikas - Dievo vaikas, } \\
\text { brolystè, seserysté }\end{array}$ & Santykis: konsultantas - klientas \\
\hline $\begin{array}{l}\text { Konsultavimo pagrindas: Meilè }+ \\
\text { t asmenị nukreipto konsultavimo } \\
\text { filosofija, metodai }\end{array}$ & $\begin{array}{l}\text { Konsultavimo pagrindas: i klientą } \\
\text { orientuoto konsultavimo filosofija, } \\
\text { metodai }\end{array}$ \\
\hline $\begin{array}{l}\text { İveikos būdai: tikèjimas Jèzaus } \\
\text { kvietimu „Ateikite“; Kristaus buvimas } \\
\text { (Mt 11, 28; Lk 10, 34) + sąmoningos, } \\
\text { valingos pastangos valdyti emocijas, } \\
\text { elgesị ir fizines reakcijas, patyrus stresą } \\
\text { sukeliančių išgyvenimų }\end{array}$ & $\begin{array}{l}\text { İveikos būdai: sąmoningos, valingos } \\
\text { pastangos valdyti emocijas, elgesị } \\
\text { ir fizines reakcijas, patyrus stresą } \\
\text { sukeliančių išgyvenimų }\end{array}$ \\
\hline $\begin{array}{c}\text { Dėmesys - i Dievo valios matymą ir jos } \\
\text { prièmimą }\end{array}$ & $\begin{array}{c}\text { Dèmesys - i savirealizaciją ir } \\
\text { individualizaciją }\end{array}$ \\
\hline
\end{tabular}

3 pav. Dvasinio ir psichologinio konsultavimo palyginimas

Apibendrinant galima teigti, kad tam tikrais atvejais ir psichoterapija galètų padèti ieškoti Kūrèjo žmoguje, ne tik koreguoti sutrikusius reakcijų i stimulus mechanizmus. Tada ji jau galètų būti vadinama sielogyda (Véželienè, 2018, p. 374), ne tik todèl, kad apima somatinę, psichinę bei dvasinę sritis, bet ir todèl, kad paveda negalias Kūrejui, remiasi meilès ir empatijos principais.

\section{Apibendrinimas}

- Dvasingumo sąvoka tam tikrame kontekste ar teorijoje gali būti traktuojama skirtingai, nepaisant to, ji visada nukreipta ị prasmès, tikslo ir gyvenimo krypties sritis.

- Dvasinio asistavimo sąvoka apima dvasinio ir psichologinio konsultavimo, kompleksinès psichosocialinès pagalbos sampratą. Dvasinio asistento krikščioniškojo mokymo ir moralès principų laikymasis konsultuojant yra skiriamasis psichologinio konsultavimo, besiremiančio pasaulietiniu psichologinių problemų sprendimo principu, 
bruožas. Svarbiausias dvasinio asistavimo veiklos matmuo - tarnystės santykis ne tik su dvasiškai ir kūniškai kenčiančiaisiais, bet ir nuolatinis santykis su Dievu.

- Dvasinis asistavimas yra svarbus dvasinès pagalbos veiksnys holistinès pagalbos kontekste, nes pagrịstas kristocentriškumo principu, pagalbą konkrečiam asmeniui traktuoja kaip visapusės dvasinès, fizinès, psichologinès ir socialinès gerovès užtikrinimą.

\section{Literatūra}

Advilonienė, Ž., Jakelè, L. (2018). Sielovadinis palydėjimas paliatyvioje slaugoje kaip pagalba sergančiajam jo kančios akivaizdoje. Soter, Nr. 68 (96), p. 29-62. Prieiga internete: https:/www.vdu.lt/cris/bitstream/20.500.12259/60139/1/ISSN2335-8785_2018_N_68_96. PG_29-62.pdf. [žiūrèta 2020-04-12].

Bagdonè, K. (2020). Dvasinis palydetojas - pagalba vidinio gijimo kelyje. Prieiga internete: http://www.bernardinai.lt/straipsnis/2020-02-13-dvasinis-palydetojaspagalba-vidinio-giji mo-kelyje/179068 [žiūrèta 2020-02-28].

Butènaitè, J. (2019). Vyresnio amžiaus Romos kataliku tikèjimas: tipai, raiška gyvenimo eigoje ir jo reikšme psichologiniam atsparumui. Daktaro disertacija. Vilnius: Mykolo Romerio universitetas. Prieiga internete: https://repository.mruni.eu/handle/007/15976 [žiūrèta 2020-05-03].

Calame, J. P. (2020). Atpažinti sandoros Dieva. Susitikti prisikèlusị Kristu: dvasinis palydejimas, vidinis gijimas, žmogaus augimas. Vilnius: Magnificat leidiniai.

Dulskis, R. (2008). Sielogyda: tarp psichoterapijos ir religijos. Prieiga internete: http://www.bernardinai.lt/straipsnis/2008-12-22-romualdas-dulskis-sielogydatarp-psichote rapijos-ir-religijos/12920 [žiūrèta 2020-05-06].

Grun, A. (2014). Pasitikèk savo jègomis: kaip ịveikti krizes. Vilnius: Katalikų pasaulio leidiniai.

Gubi, P. M. (2011). A Qualitative Exploration of the Similarities and Differences between Counselling and Spiritual Accompaniment. Prieiga internete: https:// www.researchgate.net/publication/274341278_A_Qualitative_Exploration_of the_Similarities_and_Differences_between_Counselling_and_Spiritual_Accompaniment [žiūrèta 2020-02-28].

Jagelavičius, A., Vasiliauskaitė, A., Adler-Mikulėnienė, S. (2019). Klinikinès pastoracijos sistemos sukūrimo Lietuvoje prielaidos. Soter, Nr. 69 (97), p. 29-46. Prieiga internete: https://www.vdu.lt/cris/bitstream/20.500.12259/61663/1/ISSN23358785_2019_N_69_97. PG_29-46.pdf [žiūrèta 2020-02-27]. 
Jonas Paulius II. (1984). Apaštališkasis laiškas „,Salvifici Doloris“ apie krikščioniškaja žmogiškosios kančios prasme. Prieiga internete: https://eis.katalikai.lt/vb/popieziai/jonas_paulius_ii/ap-laiskai/1984-02-11_salvifici-doloris [žiūrèta 2020-04-12].

Karaliūtè, A. (2001). Dvasinio krikščioniškojo ugdymo(si) prielaidos Lietuvos aukštojoje mokykloje. Acta Paedagogica Vilnensia, Nr. 8, p. 223-229. Prieiga internete: https://www.zurnalai.vu.lt/acta-paedagogica-vilnensia/article/view/9530/7354 [žiūrèta 2020-04-11].

Kataliku Bažnyčios Katekizmas. (2015). Vilnius: Katalikų pasaulio leidiniai.

Lanauskienè, S. (2017). Dvasinis konsultavimas - naujas būdas teikti dvasinę pagalbą. Magnificat, Nr. 7. Prieiga internete: https://www.magnificat.lt/dvasinis-konsultavimas-naujas-budas-teikti-dvasine-pagalba/ [Žiūrèta 2020-02-28].

Lavretsky, H. (2010). Spirituality and aging. Aging Health, Vol. 6. p. 749-769. 10.2217/ahe.10.70. Prieiga internete: https://www.researchgate.net/publication/271276303_Spirituality_and_aging [žiūrèta 2020-10-25].

Lietuvos Respublikos sveikatos apsaugos ministro įsakymas „Dèl sielovados patarnavimų teikimo sveikatos priežiūros įstaigose“. (2009). Prieiga internete: https://eseimas.lrs.1t/portal/legalAct/lt/TAD/TAIS.359051/asr [žiūrèta 2021-10-25].

Lietuvos Respublikos Vyriausybès nutarimas „Dėl bazinio paslaugų šeimai paketo patvirtinimo“. (2019). Prieiga internete: https://e-seimas.lrs.lt/portal/legalAct/lt/TAD/ 901a2bf698ce11e9aab6d8dd69c6da66?jfwid=nl6mpxlky [žiūrèta 2021-10-25].

Milašiūnas, R. (2017). Psichoterapija: kaip ir kodèl? Vilnius: Tyto alba.

Mowat, H., O’Neill, M. (2013). Spirituality and ageing: Implications for the care and support of older people. Prieiga internete: https://www.iriss.org.uk/resources/insights/spirituality-ageing-implications-care-support-older-people [žiūrèta 2020-10-26].

Perminas, A., Goštautas, A., Endriulaitienè, A. (2004). Asmenybe ir sveikata: teoriju squadas. Mokomoji knyga. Prieiga internete: https://www.vdu.lt/cris/handle/20.500.12259/160 [žiūrèta 2020-05-08].

Pranckevičienė, A., Žardeckaitė-Matulaitienė, K., Gustainienė, L. (2012). Kasdienė dvasingumo raiška ir jos sąsaja su sveikatai palankia gyvensena suaugusiojo amžiuje. Soter, Nr. 43 (71), p. 99-112. Prieiga internete: https://www.researchgate. net/publication/267261796_Kasdiene_dvasingumo_raiska_ir_jos_sasaja_su_ sveikatai_palankia_gyvensena_suaugusiojo_amziuje [žiūrèta 2020-03-09].

Ramonas, A. (2006). Sakramentu teologija. Doktrina. Istorija. Šventimas. Klaipeda: Klaipėdos universiteto leidykla.

Ramonas, A., Saldytè, I. (2013). Dvasinès pagalbos galimybės netiesioginès priklausomybės atveju. Tiltai. Priedas, Nr. 44, p. 114-132. Prieiga internete: https://etalpykla.lituanistikadb.lt/object/LT-LDB-0001:J.04 2013 1468176124574/[Žiūrèta 2020-05-09]. 
Redd, L. (2017). Spirituality and Aging: A Guide for Seniors on Faith, Meaning, and Connection. Prieiga internete: https:/www.greatseniorliving.com/articles/spirituality [žiūrèta 2019-10-24].

Redin, M. I. (2010). Išgydyk mane, Viešpatie: Jézus gydo šiandien. Vilnius: Katalikų pasaulio leidiniai.

Rolheiser, R. (2017). Dvasingumo paieškos. Krikščioniškojo dvasingumo gairès XXI amžiuje. Vilnius: Katalikų pasaulio leidiniai.

Scazzero, P. (2018). Emociškai brandus dvasingumas. Vilnius: Misionieriškas labdaros fondas „Šviesa Rytuose“.

Skinkaitis, R. (2016). Žmogaus, sukurto pagal Dievo paveikslą ir panašuma, teologine perspektyva. Mokslo monografija. Kaunas: Versus aureus.

Šeškevičius, A., Valiulienè, Ž. (2011). Dvasingumo raiška paliatyviojoje priežiūroje. Sveikatos mokslai, Nr. 21 (2), p. 109-114. Prieiga internete: https://sm-hs.eu/wpcontent/uploads/2019/02/34-119-1-PB.pdf [žiūrèta 2020-04-30].

Šiaudvytyte, D. (2005). Grigališkojo choralo giedojimas kaip jaunimo dvasiniu vertybiu sistemos veiksnys. Magistro darbas. Vilnius: Pedagoginis universitetas. Prieiga internete: https://vb.vdu.lt/object/elaba:1899233/index.html [žiūrèta 2018-10-21].

Vèželienè, L. (2018). Septynios didžiosios nuodèmès psichologo kabinete. Vilnius: Tyto alba.

Vorgrimler, H. (2003). Naujasis teologijos žodynas. Kaunas: katalikų interneto tarnyba.

\section{SPIRITUAL ASSISTANCE AS AN INTEGRAL PART OF SPIRITUAL SUPPORT}

\section{Vaineta Juškienè, Jolita Navickienė}

Summary

Seeking to maintain the personality's harmony and spiritual health, it is important to have an integral view of both psychological and religious dimensions while coping with these problems. Such perspective stimulates turning to Christian assistance whose relevance can significantly contribute to keeping spiritual balance, self-value, sense and dignity, which are basic features of a human being as a spiritual person. Spiritual counselling and 
assistance are one of the forms of the mentioned support that started being recognised in laws of the Republic of Lithuania (order of the Minister of Health of the Republic of Lithuania, "On Provision of Pastoral Care Services at Health Care Institutions" (2009); decree of the Government of the Republic of Lithuania "On Approval of the Basic Package of Services for a Family" (2019)) and gradually is becoming established as practice of support in various realities of life. Nevertheless, still discussions occur on conceptual aspects, terminology or definition of the said support. With regard to this, the aim of this article to reveal the features of Christian spiritual assistance in the context of the concept of spirituality and its relationship with psychological support is raised. To achieve this aim, the following research methods have been employed: literature analysis, systematisation, interpretation.

The research results demonstrate that the concept of spirituality in different contexts and theories may be treated in different ways; however, regardless of this, it is always directed towards areas of meaning, goal and direction of life. The concept of spirituality is characteristic of multiple aspects; therefore, it is important to identify the features of Christian spirituality. God is the centre, object and aim of Christian spirituality that manifests in personal life of a human. Therefore, Christian spirituality is Christ-centred and human's interpersonal life with God.

The concept of spiritual assistance has notions of spiritual and psychological counselling, complex psychological support intertwined. The principles of Christian teaching and morality being kept by a spiritual assistant while counselling is a distinctive feature making it different from psychological counselling based on the secular method for solving psychological problems. The relationship of serving not only spiritually and corporally suffering individuals, but also a continuous relationship with God is the most important measure of spiritual assistance.

Spiritual assistance is an important factor of spiritual support in the context of holistic assistance because it is based on the Christ-centred principle, treats support for a particular person as assurance of comprehensive condition of spiritual, physical, psychological and social wellbeing. 